\title{
Discovery of Kynurenines Containing Oligopeptides as Potent Opioid Receptor Agonists
}

\author{
Edina Szúcs 1,2, Azzurra Stefanucci ${ }^{3, *}$, Marilisa Pia Dimmito ${ }^{3}$, Ferenc Zádor ${ }^{1}$, \\ Stefano Pieretti ${ }^{4}(\mathbb{D})$, Gokhan Zengin ${ }^{5}$ (D) , László Vécsei ${ }^{6}$, Sándor Benyhe ${ }^{1}$, Marianna Nalli ${ }^{7}$ and \\ Adriano Mollica ${ }^{3}$ iD
}

1 Institute of Biochemistry, Biological Research Center, Hungarian Academy of Sciences, Temesvári krt. 62., H-6726 Szeged, Hungary; szucs.edina@brc.hu (E.S.); zador.ferenc@brc.hu (F.Z.); benyhe.sandor@brc.hu (S.B.)

2 Doctoral School of Theoretical Medicine, Faculty of Medicine, University of Szeged, Dómtér 10, H-6720 Szeged, Hungary

3 Department of Pharmacy, University of Chieti-Pescara "G. d'Annunzio", Via dei Vestini 31, 66100 Chieti, Italy; marilisa.dimmito@unich.it (M.P.D.); a.mollica@unich.it (A.M.)

4 National Center for Drug Research and Evaluation, Istituto Superiore di Sanità, Viale Regina Elena 299, 00161 Rome, Italy; stefano.pieretti@iss.it

5 Department of Biology, Science Faculty, Selcuk University, 42250 Konya, Turkey; gokhanzengin@selcuk.edu.tr

6 MTA-SZTE Neuroscience Research Group, Department of Neurology, Interdisciplinary Excellence Centre, Faculty of Medicine, University of Szeged, H-6725 Szeged, Hungary; vecsei.laszlo@med.u-szeged.hu

7 Laboratory affiliated with the Institute Pasteur Italy-Cenci Bolognetti Foundation, Department of Drug Chemistry and Technologies, Sapienza University of Rome, Piazzale Aldo Moro 5, I-00185 Roma, Italy; marianna.nalli@uniroma1.it

* Correspondence: a.stefanucci@unich.it

Received: 27 December 2019; Accepted: 6 February 2020; Published: 12 February 2020 updates

\begin{abstract}
Kynurenine (kyn) and kynurenic acid (kyna) are well-defined metabolites of tryptophan catabolism collectively known as "kynurenines", which exert regulatory functions in host-microbiome signaling, immune cell response, and neuronal excitability. Kynurenine containing peptides endowed with opioid receptor activity have been isolated from natural organisms; thus, in this work, novel opioid peptide analogs incorporating L-kynurenine (L-kyn) and kynurenic acid (kyna) in place of native amino acids have been designed and synthesized with the aim to investigate the biological effect of these modifications. The kyna-containing peptide (KA1) binds selectively the $\mu$-opioid receptor with a $\mathrm{Ki}=1.08 \pm 0.26$ (selectivity ratio $\mu / \delta / \kappa=1: 514: 10,000$ ), while the L-kyn-containing peptide (K6) shows a mixed binding affinity for $\mu, \delta$, and $\kappa$-opioid receptors, with efficacy and potency $\left(\mathrm{E}_{\max }=209.7+3.4 \% ; \log \mathrm{EC}_{50}=-5.984+0.054\right)$ higher than those of the reference compound DAMGO. This novel oligopeptide exhibits a strong antinociceptive effect after i.c.v. and s.c. administrations in in vivo tests, according to good stability in human plasma ( $\left.\mathrm{t}_{1 / 2}=47 \mathrm{~min}\right)$.
\end{abstract}

Keywords: peptides; kynurenines; binding affinity; $\mu$-opioid receptor; pharmacophore; G-protein activation

\section{Introduction}

The kynurenine pathway (KP) is an essential part of the tryptophan metabolism in mammalian tissues, where it is responsible for the formation of two principal metabolites, namely, L-kynurenine (kyn) and kynurenic acid (kyna). Kyn can arise in peptides and proteins by post/translational modifications or direct oxidation of tryptophan. It is present in lens crystallins, human $\mathrm{Cu}^{2+} / \mathrm{Zn}^{2+}$ dismutase, milk proteins, actin oxidized in vivo, and several bioactive compounds produced by bacteria 
and marine organisms [1]. Daptomycin is a cyclic kyn-containing lipodepsipeptide approved by the Food and Drug Administration (FDA), isolated from Streptomyces roseoporus used in the treatment of Gram-positive pathogen skin infections [2]. Cyclomontanin B isolated from Annona montana exhibits promising anti-inflammatory activity [3]. The kyn-containing peptide FP-Kyn-L-NH $\mathrm{N}_{2}$ is the minor component of Australian red tree frog skin Litoria rubella collected in central Australia, endowed with opioid activity at $10^{-7} \mathrm{M}$ (Figure 1) [4].

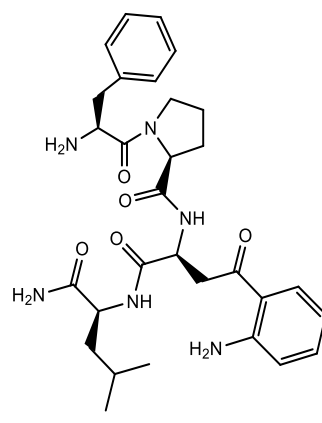

FP-Kyn-L-NH

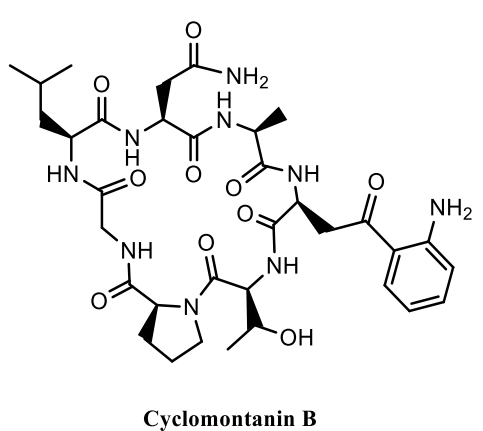

Cyclomontanin B

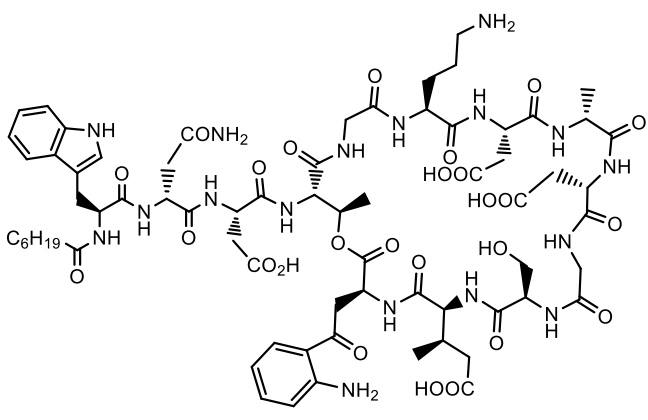

Daptomycin

Figure 1. Natural bioactive compounds containing kyn residue.

The occurrence of kyn in natural products suggests a possible specificity towards their biological targets. The enzymes of the human kynurenine pathway are expressed in different tissues and cell types throughout the body [1]. In humans, the majority of kyn is excreted by urine; thus, its bioavailability increases according to the tryptophan flux downstream of the KP [5]. Kyn is able to penetrate the central nervous system (CNS) by transport across the blood-brain barrier (BBB), but it is also produced locally [6].

Kyna has been originally discovered in canine urine, but a huge amount has been measured in the gut, bile, human saliva, synovial and amniotic fluid; it has also been detected in food products such as broccoli, some potatoes, and honeybee products [1]. Kyna possesses an antagonistic effect on the N-methyl-D-aspartate (NMDA) receptor and other glutamate receptors such as AMPA and kainate receptors $[7,8]$. Kyna is also found to have an agonistic effect on the $G$ protein coupled receptor GPR35 [9,10], which can be found in various tissues and organs such as gastrointestinal tract, liver, immune system, central nervous system, and cardiovascular system [11]. NMDA receptors are essential for the control of the glutamatergic work at the CNS; in contrast to the kainate and AMPA receptors, the NMDA mediates the influx of $\mathrm{Ca}^{2+}$ ions into neurons, playing an important role in synaptic plasticity, memory, and learning [7,8]. Overactivation of NMDA receptors can lead to excitotoxicity, severe cell damage, and apoptosis of neurons, which are strongly related to neurodegenerative and CNS disorders such as depression, stroke, ischemia, and neuropathic pain [10-12]. Different therapeutic approaches based on thekynurenine pathway have been postulated to circumvent this problem, such as the use of kynurenic acid prodrugs or analogs able to penetrate more readily than the parent compounds or the involvement of ascorbate conjugation to promote the interaction of kyna with SVCT2 transport protein [13-15]. Intracisternal kyna attenuates formalin-induced nociception in animals together with antagonist activity at the glycine binding site of NMDA, which is associated with analgesic properties in rats [16]. At the peripheral sites, kyna decreases the nociceptive behavior in the tail flick and hot plate tests [16]. Administration of L-kyn and probenecid together with kyna analogs inhibits NMDA receptors in animal models of trigeminal activation and sensitization [17]. Noteworthy, kyna and its analogs are able to act on second-order neurons, decreasing mechanical allodynia and pain sensitivity in different animal pain models [18]. Considering the presence of kyn residue in natural peptide sequences and the important role exerted by both kynurenines at the CNS [19-21], we plan to investigate the biological consequences of the insertion of these residues in opioid pharmacophoric sequences. Kyn could be used in place of phenylalanine, considering its aromatic side chain, whereas 
kyna could be used as $C$-terminus to mimic an additional aromatic residue. In this preliminary work, we performed the synthesis and biological screening of six novel kynurenines containing peptides, aiming to investigate the modifications imposed by the presence of kyn and kyna on the biological properties of known endogenous and synthetic opioid peptides in vivo and in vitro. Peptide KA1 retains the DAMGO primary sequence, but the $\mathrm{OH}$ terminal group is esterified by kynurenic acid. Peptides K2 and K3 are EM-2 analogs in which the Phe residues in positions 3 and 4 have been replaced with kyn and kyn C-terminal amides, respectively. Peptides K4-K6 are enkephalin-like peptides containing kyn in position 5 , bearing as $C$-terminal the methyl ester, acid, and amide group, respectively. The novel chemical entities were prepared following solution phase peptide synthesis and were obtained as TFA salts in good overall yields and excellent purities.

\section{Materials and Methods}

\subsection{Chemistry}

All reagents and solvents were acquired from Sigma-Aldrich (Milano, Italy). Solution phase peptide synthesis was applied to prepare the final products KA1, K2-K6 as TFA salts, following the procedures reported below. Boc-protected intermediates were purified by silica gel column chromatography where necessary, or by trituration in $\mathrm{Et}_{2} \mathrm{O}$. Final products KA1, K2-K6 were purified by RP-HPLC on a Waters XBridge BEH130 (C18 $5.0 \mu \mathrm{m}, 250 \times 10 \mathrm{~mm}$ column; flow rate of $7 \mathrm{~mL} / \mathrm{min}$; Waters Binary pump 1525; eluent: linear gradient of $\mathrm{H}_{2} \mathrm{O} / \mathrm{ACN} 0.1 \%$ TFA, ranging from $5 \%$ to $95 \%$ ACN in $32 \mathrm{~min}$ ). The purity of the $N^{\alpha}$-Boc-protected products was confirmed by NMR analysis on a Varian Mercury $300 \mathrm{MHz}$. The purity of all final compounds was assessed by NMR analysis, ESI-LRMS, and by analytical RP-HPLC (C18-bonded $4.6 \times 150 \mathrm{~mm}$; flow rate of $1 \mathrm{~mL} / \mathrm{min}$; eluent: gradient of $\mathrm{H}_{2} \mathrm{O} / \mathrm{ACN} 0.1 \%$ TFA, ranging from $5 \%$ to $95 \% \mathrm{ACN}$ in $26 \mathrm{~min}$, recorded at 254, 275, and $213 \mathrm{~nm}$ and was found to be $\geq 95 \%$ ). The mass spectrometry (MS) equipment was composed as follows: LCQ Thermo Finnigan ion trap mass spectrometer (San Jose, CA, USA) with an electrospray ionization (ESI) source; capillary temperature: $300{ }^{\circ} \mathrm{C}$; spray voltage: $4.00 \mathrm{kV}$; nitrogen $\left(\mathrm{N}_{2}\right)$ as the sheath and auxiliary gas.

\subsection{General Procedures}

\subsubsection{Formation of Ethanolamine-Kynurenic Acid Ester}

Kynurenic acid ( $2 \mathrm{mmol}, 1$ equiv.) was dissolved in DMF $(5 \mathrm{~mL})$ stirring in agitation at $0{ }^{\circ} \mathrm{C}$, then a mixture of Boc- $N$-aminoethanol ( 2 mmol, 1 equiv.) and DMAP $(0.6 \mathrm{mmol}, 0.3$ equiv. $)$ in DMF ( $3 \mathrm{~mL})$ was transferred in the round bottom flask. After $10 \mathrm{~min}, \mathrm{EDC} . \mathrm{HCl}(2.2 \mathrm{mmol}, 1.1$ equiv. $)$ was added to the reaction mixture in agitation at $0{ }^{\circ} \mathrm{C}$ for $10 \mathrm{~min}$, then at r.t. overnight. The solvent was removed in a rotary evaporator and the oily residue was taken up with EtOAc and washed with 5\% citric acid solution ( 3 times), $\mathrm{NaHCO}_{3}$ s.s. (3 times), and $\mathrm{NaCl}$ s.s. (3 times). Organic phases were collected and dried on $\mathrm{Na}_{2} \mathrm{SO}_{4}$ anhydrous, filtered and dried in rotavapor and high vacuum to give a yellow oily product. The crude product was triturated with $\mathrm{Et}_{2} \mathrm{O}$ (2 times), the aqueous layer filtered up, and the white solid product dried in a rotary evaporator and high vacuum.

\subsubsection{Coupling Reaction}

Boc-protected compound (1.1 equiv.) was dissolved in DMF $(5 \mathrm{~mL})$ in an iced-cooled bottom flask, then $\mathrm{EDC} . \mathrm{HCl}$ (1.1 equiv.) and $\mathrm{HOBt}$ hydrate (1.1 equiv.) were added stirring for $10 \mathrm{~min}$. A solution of $\mathrm{N}$-terminal free intermediate (1 equiv.) and DIPEA (3.3 equiv.) in DMF $(5 \mathrm{~mL})$ was transferred in the ice-cooled bottom flask at $0{ }^{\circ} \mathrm{C}$ and allowed to react at r.t. overnight. The solvent was removed in a rotary evaporator; the oily residue was taken up with EtOAc and washed with $5 \%$ citric acid solution ( 3 times), $\mathrm{NaHCO}_{3}$ s.s. (3 times), and $\mathrm{NaCl}$ s.s. (3 times). Organic phases were collected and dried on $\mathrm{Na}_{2} \mathrm{SO}_{4}$ anhydrous, filtered and dried in a rotavapor and high vacuum to give a yellow oily product. 
The crude product was triturated with $\mathrm{Et}_{2} \mathrm{O}$ (2 times), the aqueous layer filtered up and the white solid product dried in a rotary evaporator and high vacuum.

\subsubsection{Amidation}

The Boc-protected or free $\mathrm{N}$-terminal compound (1 equiv.) was dissolved in THF $(7 \mathrm{~mL})$ stirring at $-15^{\circ} \mathrm{C}$, then $\mathrm{NMM}$ (2.5 equiv.) and $i \mathrm{BCF}$ (2.1 equiv.) were added to the solution allowing to react for $30 \mathrm{~min}$. Then $\mathrm{NH}_{4} \mathrm{OH}$ aq. solution $(0.21 \mathrm{~mL})$ was added to the reaction mixture at $-15^{\circ} \mathrm{C}$ for $30 \mathrm{~min}$. The reaction mixture was allowed to react at r.t. for $2 \mathrm{~h}$. The solvent was removed in rotavapor and the solid residue was dissolved in EtOAc washing with 5\% citric acid solution (3 times), $\mathrm{NaHCO}_{3}$ s.s. ( 3 times), and $\mathrm{NaCl}$ s.s. (3 times). Organic phases were collected and dried on $\mathrm{Na}_{2} \mathrm{SO}_{4}$ anhydrous, filtered and dried in a rotavapor and high vacuum to give a yellow oily product. The crude product was triturated with $\mathrm{Et}_{2} \mathrm{O}$ (2 times), the aqueous layer filtered up, and the product dried in a rotary evaporator and high vacuum to give a white solid product.

\subsubsection{Saponification}

Boc-protected compound ( $0.1 \mathrm{mmol}, 1$ equiv.) was dissolved in THF $(5 \mathrm{~mL})$ stirring at r.t. then $\mathrm{NaOH} 1 \mathrm{M}$ (4 equiv.) was added dropwise, allowing it to react for $3 \mathrm{~h}$. The solvent was removed in a rotavapor; the oily residue was taken up with water and washed with $\mathrm{Et}_{2} \mathrm{O}$ ( 2 times). The aqueous solution was acidified with $\mathrm{HCl} 1 \mathrm{M}$ until complete precipitation of the solid residue, which was extracted with EtOAc 3 times. The organic layers were collected, dried on $\mathrm{Na}_{2} \mathrm{SO}_{4}$ anhydrous, filtered and dried in a rotavapor and high vacuum to give a white solid product.

\subsection{Synthesis and Characterization}

Description of the reaction procedures [22-24] and compounds characterization are reported in detail in the Supplementary Materials.

\subsection{In Vitro Biological Assays}

\subsubsection{Chemicals}

Tris- $\mathrm{HCl}$ EGTA, $\mathrm{NaCl}, \mathrm{MgCl}_{2} \cdot 6 \mathrm{H}_{2} \mathrm{O}, \mathrm{GDP}$, the GTP analog GTP $\gamma \mathrm{S}$, and the L-tryptophan metabolite kynurenic acid were from Sigma-Aldrich (Budapest, Hungary); Tyr-D-Ala-Gly-(NMe)Phe-Gly-ol (DAMGO) was purchased from Bachem Holding AG (Bubendorf, Switzerland); endomorphin-2 (EM-2) was kindly provided by MTA-ELTE Research Group of Peptide Chemistry (Budapest, Hungary); Ile ${ }^{5,6}$-deltorphine II (Ile ${ }^{5,6}$ Delt II) was purchased from Isotope Laboratory of BRC (Szeged, Hungary); and the highly selective KOR agonist diphenethylamine derivative, HS665 [25], was offered by Dr. Helmut Schmidhammer (University of Innsbruck, Austria). Naloxone was provided by Endo Laboratories DuPont de Nemours (Wilmington, DE, USA). The non-competitive NMDA antagonist, (+)-MK 801 maleate (MK-801) and L-kynurenine (L-kyn) were obtained from Tocris Bioscience (Bristol, UK). A solution of each ligand in water was stored in $1 \mathrm{mM}$ stock solution at $-20{ }^{\circ} \mathrm{C}$. The radiolabelled GTP analog, $\left[{ }^{35} \mathrm{~S}\right] \mathrm{GTP} \gamma \mathrm{S}$ (specific activity: $1000 \mathrm{Ci} / \mathrm{mmol}$ ), was acquired from Hartmann Analytic (Braunschweig, Germany). [ $\left.{ }^{3} \mathrm{H}\right]$ DAMGO [26] (specific activity: $38.8 \mathrm{Ci} / \mathrm{mmol}$ ), $\left[{ }^{3} \mathrm{H}\right] \mathrm{Il} e^{5,6}$ Delt II (specific activity: $19.6 \mathrm{Ci} / \mathrm{mmol}$ ), and $\left[{ }^{3} \mathrm{H}\right] \mathrm{HS} 665$ [27] (specific activity: $13.1 \mathrm{Ci} / \mathrm{mmol}$ ) were radiolabelled in the Isotope Laboratory of BRC (Szeged, Hungary). [ $\left.{ }^{3} \mathrm{H}\right] \mathrm{MK}-801$ [28] (specific activity: $30 \mathrm{Ci} / \mathrm{mmol}$ ) was purchased from PerkinElmer (Boston, MA, USA) and the UltimaGold ${ }^{\mathrm{TM}}$ MV aqueous scintillation cocktail was from PerkinElmer (Boston, MA, USA).

\subsubsection{Animal}

Male and female Wistar rats and guinea pigs were used for membrane preparations. The animals were guarded in a temperature-controlled room, ranging from 21 to $24^{\circ} \mathrm{C}$, under a 12:12 light and dark cycle with water and food ad libitum. All housing and experiments were conducted in accordance with 
the European Communities Council Directives (86/606/ECC) and the Hungarian Act for the Protection of Animals in Research (XXVIII.tv. 32.§). The total number of animals, as well as their suffering, was minimized whenever possible.

\subsubsection{Preparation of Brain Samples for Binding Assays}

Rats and guinea pigs were decapitated, and their brains were quickly removed. The brains were used for membrane preparation following the procedure reported by Benyhe [29] for binding and $\left[{ }^{35} \mathrm{~S}\right] \mathrm{GTP} \gamma \mathrm{S}$ binding experiments, in agreement with the protocol of Zádor et al. [30].

Homogenization of brains was performed in 30 volumes $(v / w)$ of ice-cold $50 \mathrm{mM}$ Tris- $\mathrm{HCl} \mathrm{pH} 7.4$ buffer with a Teflon-glass Braun homogenizer at $1500 \mathrm{rpm}$. The centrifuge was settled at 18,000 rpm for $20 \mathrm{~min}$ at $4{ }^{\circ} \mathrm{C}$, the resulting supernatant discarded, and the pellet taken up in the original volume of Tris- $\mathrm{HCl}$ buffer. Incubation of homogenate at $37^{\circ} \mathrm{C}$ for $30 \mathrm{~min}$ was performed in a shaking water-bath. Five volumes of $50 \mathrm{mM}$ Tris- $\mathrm{HCl}$ pH 7.4 buffer were used to suspend the final pellet at $-80{ }^{\circ} \mathrm{C}$. For the $\left[{ }^{35} \mathrm{~S}\right] \mathrm{GTP} \gamma \mathrm{S}$ binding experiments, the brains were homogenized with a Dounce in 5 volumes $(\mathrm{v} / \mathrm{w})$ of ice-cold TEM (Tris- $\mathrm{HCl}, \mathrm{EGTA}, \mathrm{MgCl}_{2}$ ) at $-80^{\circ} \mathrm{C}$. The protein content of the membrane preparation was determined by the method of Bradford, BSA being used as a standard [31].

\subsubsection{Receptor Binding Assays}

\section{Functional $\left[{ }^{35} \mathrm{~S}\right] \mathrm{GTP} \gamma \mathrm{S}$ Binding Experiments}

The functional $\left[{ }^{35} \mathrm{~S}\right] \mathrm{GTP} \gamma \mathrm{S}$ binding experiments were performed as previously described $[32,33]$. Briefly the membrane homogenates were incubated at $30{ }^{\circ} \mathrm{C}$ for $60 \mathrm{~min}$ in Tris-EGTA buffer (pH 7.4) composed of $50 \mathrm{mM}$ Tris-HCl, $1 \mathrm{mM}$ EGTA, $3 \mathrm{mM} \mathrm{MgCl}$, $100 \mathrm{mM} \mathrm{NaCl}$, containing $20 \mathrm{MBq} / 0.05 \mathrm{~cm}^{3}$ $\left.{ }^{35} \mathrm{~S}\right] \mathrm{GTP} \gamma \mathrm{S}(0.05 \mathrm{nM})$ and increasing concentrations $\left(10^{-10}\right.$ to $\left.10^{-5} \mathrm{M}\right)$ of ligands. The experiments were performed in the presence of excess GDP $(30 \mu \mathrm{M})$ in a final volume of $1 \mathrm{~mL}$. Total binding was measured in the absence of test compounds, non-specific binding was determined in the presence of $10 \mu \mathrm{M}$ unlabeled GTP $\gamma \mathrm{S}$. The reaction was terminated by rapid filtration under vacuum and washed three times with $5 \mathrm{~mL}$ ice-cold $50 \mathrm{mM}$ Tris- $\mathrm{HCl}$ (pH 7.4) buffer through Whatman GF/B glass fibers. The radioactivity of the filters was detected in an UltimaGold ${ }^{\mathrm{TM}} \mathrm{MV}$ aqueous scintillation cocktail with a Packard Tricarb 2300TR liquid scintillation counter.

\section{Binding Experiments}

In MOR, DOR, and KOR displacement, aliquots of frozen rat and guinea pig brain membrane homogenates were thawed and suspended in $50 \mathrm{mM}$ Tris- $\mathrm{HCl}$ buffer ( $\mathrm{pH}$ 7.4); in NMDA displacement, the Tris- $\mathrm{HCl}$ buffer ( $\mathrm{pH}$ 7.4) contained $100 \mu \mathrm{M}$ glycine and $100 \mu \mathrm{M}$ L-glutamic acid. Samples were incubated in the presence of the unlabeled ligands in increasing concentrations $\left(10^{-10}\right.$ to $\left.10^{-5} \mathrm{M}\right)$ for at $35^{\circ} \mathrm{C}$ for $45 \mathrm{~min}$ with $\left[{ }^{3} \mathrm{H}\right] \mathrm{DAMGO}$, for at $35^{\circ} \mathrm{C}$ for $45 \mathrm{~min}$ with $\left[{ }^{3} \mathrm{H}\right] \mathrm{Ile} \mathrm{e}^{5,6} \mathrm{Delt} \mathrm{II}$, at $25^{\circ} \mathrm{C}$ for $30 \mathrm{~min}$ with $\left[{ }^{3} \mathrm{H}\right] \mathrm{HS} 665$, and at $25{ }^{\circ} \mathrm{C}$ for $120 \mathrm{~min}$ with $\left[{ }^{3} \mathrm{H}\right] \mathrm{MK}-801$. The non-specific and total binding was determined in the presence and absence of $10 \mu \mathrm{M}$ unlabelled naloxone (MOR and DOR), HS665 (KOR), and MK-801 (NMDA). Radioactivity of the filter disks was measured, as written above.

\section{Data Analysis}

Experimental data are presented as means \pm S.E.M. Sigmoid dose-response curves were fitted with GraphPad Prism 5.0 (GraphPad Prism Software Inc., San Diego, CA, USA). An unpaired $t$-test with two-tailed $p$ value was performed to determine the significance level. In the competition binding assays, the 'One site competition' fitting was used to establish the equilibrium binding affinity $\left(\mathrm{K}_{\mathrm{i}}\right.$ value). 


\subsection{In Vivo Tests}

\subsubsection{Animals}

In our experiments, we used CD-1 male mice (Harlan, Italy, 25-30 g) maintained in colony, housed in cages (7 mice per cage) under standard light/dark cycle (from 7:00 a.m. to 7:00 p.m.), temperature $\left(21 \pm 1{ }^{\circ} \mathrm{C}\right)$ and relative humidity $(60 \% \pm 10 \%)$ for at least 1 week. Food and water were available ad libitum. The Service for Biotechnology and Animal Welfare of the Istituto Superiore di Sanità and the Italian Ministry of Health authorized the experimental protocol according to Legislative Decree 26/14.

\subsubsection{Treatment Procedure}

DMSO was purchased from Merck (Rome, Italy). Peptides solutions were freshly prepared using saline containing $0.9 \% \mathrm{NaCl}$ and $\mathrm{DMSO}$ in the ratio DMSO/saline $1: 5 v / v$ every experimental day. These solutions were injected at a volume of $10 \mu \mathrm{L} /$ mouse for intracerebroventricular (i.c.v.) administrations or at a volume of $20 \mu \mathrm{L} /$ mouse for subcutaneous administrations.

\subsubsection{Surgery for i.c.v. Injections}

For i.c.v. injections, mice were lightly anesthetized with isoflurane, and an incision was made in the scalp, and the bregma was located. Injections were performed using a $10 \mu \mathrm{L}$ Hamilton microsyringe equipped with a 26-gauge needle, $2 \mathrm{~mm}$ caudal and $2 \mathrm{~mm}$ lateral from the bregma at a depth of $3 \mathrm{~mm}$.

\subsubsection{Tail Flick Test}

The tail flick latency was obtained using a commercial unit (Ugo Basile, Gemonio, Italy), consisting of an infrared radiant light source (100 W, $15 \mathrm{~V}$ bulb) focused onto a photocell utilizing an aluminum parabolic mirror. During the trials, the mice were gently hand-restrained using leather gloves. Radiant heat was focused 3-4 cm from the tip of the tail, and the latency (s) of the tail withdrawal to the thermal stimulus was recorded. The measurement was interrupted if the latency exceeded the cut off time $(15 \mathrm{~s}$ at $15 \mathrm{~V})$. The baseline latency was calculated as mean of three readings recorded before testing at intervals of $15 \mathrm{~min}$ and the time course of latency determined at 15, 30, 45, 60, 90, and $120 \mathrm{~min}$ after treatment. Data were expressed as time course of the maximum percentage effect $(\% \mathrm{MPE})=$ (post-drug latency - baseline latency)/(cut-off time - baseline latency) $\times 100$.

\subsubsection{Formalin Test}

In the formalin test, the injection of a dilute solution of formalin $(1 \%, 20 \mu \mathrm{L} / \mathrm{paw})$ into the dorsal surface of the mouse hind paw evoked biphasic nociceptive behavioral responses, such as licking, biting the injected paw, or both, occurring from 0 to $10 \mathrm{~min}$ after formalin injection (the early phase) and a prolonged phase, occurring from 15 to $40 \mathrm{~min}$ (the late phase). Before the test, mice were individually placed in a Plexiglas observation cage $(30 \times 14 \times 12 \mathrm{~cm})$ for one hour, to acclimatize to the testing environment. The total time the animal spent licking or biting its paw during the early and late phase of formalin-induced nociception was recorded.

\subsubsection{Data Analysis and Statistics}

Experimental data were expressed as mean \pm s.e.m. In the tail flick test, significant differences among the groups were evaluated with two-way ANOVA followed by Sidak's multiple comparisons test. Formalin test data were analyzed by using one-way ANOVA, followed by Holm-Sidak's multiple comparisons test. GraphPad Prism 6.03 software was used for all the analyses. Statistical significance was set at $p<0.05$. The data and statistical analysis comply with the recommendations on experimental design and analysis in pharmacology. 


\subsection{Stability in Human Plasma Sample Preparation}

Five microliters of $\mathbf{K} 6$ (500 $\mu \mathrm{g}$ in $250 \mu \mathrm{L}$ of water) were added to $45 \mu \mathrm{L}$ of fresh human plasma, then incubated at $37 \pm 1^{\circ} \mathrm{C}$. Prepared samples were removed at several designated time points and incubation was stopped by adding an equal volume of the sequencing mixture (5\% aqueous $\mathrm{ZnSO}_{4}$ solution, $\mathrm{MeOH}$, and $\mathrm{ACN}$; 5:3:2), which precipitated proteins, to achieve a final concentration of $100 \mu \mathrm{g} / \mathrm{mL}$. The mixture was vortexed and centrifuged at $12,000 \times g$ for $5 \mathrm{~min}$, then $20 \mu \mathrm{L}$ of clear supernatant was directly injected into the HPLC system (Waters model 600 solvent pump and 2996 photodiode array detector, with XBridge BEH $130 \mathrm{C} 18,4.6 \times 250 \mathrm{~mm}, 5 \mu \mathrm{m})$. The samples were tested in three independents experiments $(n=3)$ and reported values represent the mean \pm standard error (SEM). Data were analysed using simple regression analysis (significant deviation from zero: $\mathrm{F}_{1,13}=$ 171.9, $p<0.0001 ; \mathrm{Y}=-0.9705 \times \mathrm{X}+95.98)$.

\section{Results and Discussion}

\subsection{Chemistry}

Simple modifications of kyna scaffold through the insertion of aromatic substituents [34], C-terminal derivatization as methyl ester [35], or amide bearing a water-soluble side chain [36] have been abundantly documented in the literature, rather than the insertion of kyna into a peptide sequence. On the contrary, different papers highlight the scarce propensity of the kyn carboxylic group to react with $N$-terminus free amino acids involved in the coupling reaction, which renders this unusual amino acid difficult to manage as a building block for peptide synthesis [22,23].

Taking this in mind, we focused our attention on the functionalization of kyna via a variant of Steglich esterification with the previously prepared Boc-protected 2-aminoethanol [23] so as to obtain intermediate 2 in 60\% yield after purification by column chromatography (see General Procedure) [24]. Compound 2 was deprotected with a mixture of TFA:DCM = 1:1 at r.t. for $1 \mathrm{~h}$ and the so obtained intermediate was coupled with Boc- $N(\mathrm{Me}) \mathrm{Phe}-\mathrm{OH}$, following the standard procedure for coupling reaction [36].

Peptide elongation/deprotection steps were repeated to reach the complete Boc-protected peptide 6 in $66 \%$ yield, starting from intermediate compound 5, after silica gel column chromatography (Scheme 1). The final peptide KA1 has been obtained in 71\% yield after RP-HPLC purification. The purity of the sample was assessed by analytical RP-HPLC recorded at $254 \mathrm{~nm}$ and was found to be $\geq 95 \%$. 


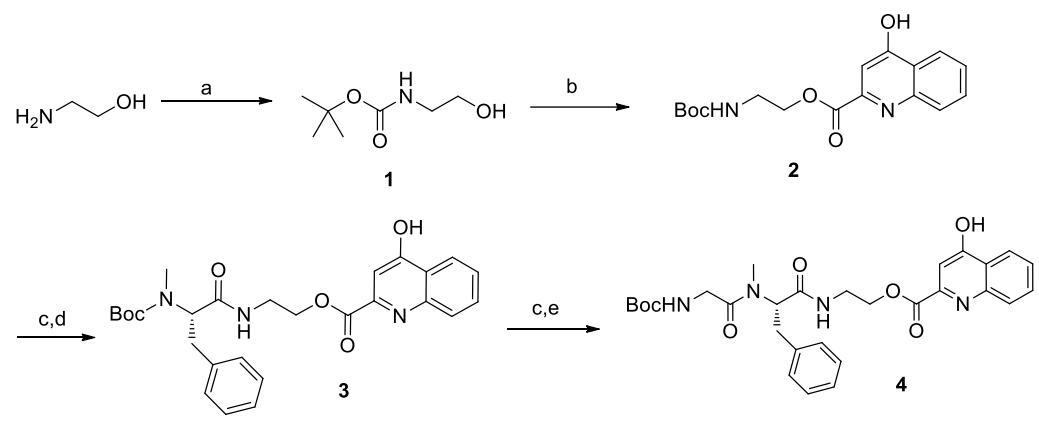<smiles>CC(NC(=O)CNC(=O)CN(C)C(=O)[C@H](Cc1ccccc1)NCCOC(=O)c1cc(O)c2ccccc2n1)C(=O)NCc1ccccc1</smiles><smiles>CC(C)C(=O)NC(Cc1ccc(O)cc1)C(=O)NC(C)C(=O)NCC(=O)N(C)[C@H](Cc1ccccc1)C(=O)NCCOC(=O)c1cc(O)c2ccccc2n1</smiles><smiles>CC(C(=O)NCC(=O)N(C)[C@H](Cc1ccccc1)C(=O)NCCOC(=O)c1cc(O)c2ccccc2n1)C(=O)NC(Cc1ccc(O)cc1)C(F)(F)F</smiles>

Scheme 1. Synthesis of peptide KA1. Reagents and conditions: (a) $\mathrm{Boc}_{2} \mathrm{O}, \mathrm{NaOH} 1 \mathrm{M}, \mathrm{THF}, 10 \mathrm{~min}$ at $0{ }^{\circ} \mathrm{C}$, then $16 \mathrm{~h}$ at r.t. quantitative; (b) kynurenic acid, EDC. $\mathrm{HCl}$, DMAP, DMF, $10 \mathrm{~min}$ at $0{ }^{\circ} \mathrm{C}$, then $36 \mathrm{~h}$ at r.t., $60 \%$ yield after silica gel column chromatography; (c) TFA/DCM 1:1 $1 \mathrm{~h}$ at r.t. quantitative; (d) Boc-N-Me-Phe-OH, EDC.HCl, HOBt, DIPEA, DMF, 10 min at $0{ }^{\circ} \mathrm{C}$, then $16 \mathrm{~h}$ at r.t., $75 \%$ yield after reaction work-up; (e) Boc-Gly-OH, EDC.HCl, HOBt, DIPEA, DMF, $10 \mathrm{~min}$ at $0{ }^{\circ} \mathrm{C}$, then $16 \mathrm{~h}$ at r.t., $70 \%$ yield after reaction work-up; (f) Boc-DAla-OH, EDC.HCl, $\mathrm{HOBt}$, DIPEA, DMF, $10 \mathrm{~min}$ at $0{ }^{\circ} \mathrm{C}$, then $16 \mathrm{~h}$ at r.t., $80 \%$ yield after silica gel column chromatography; (g) Boc-Tyr-OH, EDC.HCl, HOBt, DIPEA, $\mathrm{DMF}, 10 \mathrm{~min}$ at $0{ }^{\circ} \mathrm{C}$, then $16 \mathrm{~h}$ at r.t., $66 \%$ yield from 5 , after silica gel column chromatography.

Then L-kyn was converted in its Boc-derivative 7 following the procedure reported by Tsentalovich et al. [23] to prepare the EM-2 analogs K2 and K3 (Scheme 2). Firstly intermediate 7 was coupled with $\mathrm{H}-\mathrm{Phe}-\mathrm{NH}_{2}$, previously prepared following the general procedure of amidation, to obtain intermediate 8 in $61 \%$ yield. The Boc-protecting group was removed from compound 8 , and the so obtained TFA salt was coupled with Boc-Pro-OH to give intermediate 9 in good yield (81\%). Repeated steps of coupling/purification/deprotection afforded the final compound $\mathrm{K} 2$ in $72 \%$ yield from 10, and excellent purity after RP-HPLC purification of the crude product. Conversely, Boc-Kynurenine $\mathbf{7}$ was transformed in the amide Boc-derivative $\mathbf{1 1}$ in a 71\% yield. Then it was deprotected with a mixture of TFA:DCM = 1:1 at r.t. for $1 \mathrm{~h}$ and the so obtained TFA salt was coupled with BocPhe-OH to afford intermediate $\mathbf{1 2}$ quantitatively. Then repeated steps of coupling/purification/deprotection were performed to reach peptide $\mathbf{K} 3$ in high yield (83\% from 14) and excellent purity after RP-HPLC purification of the crude compound. 


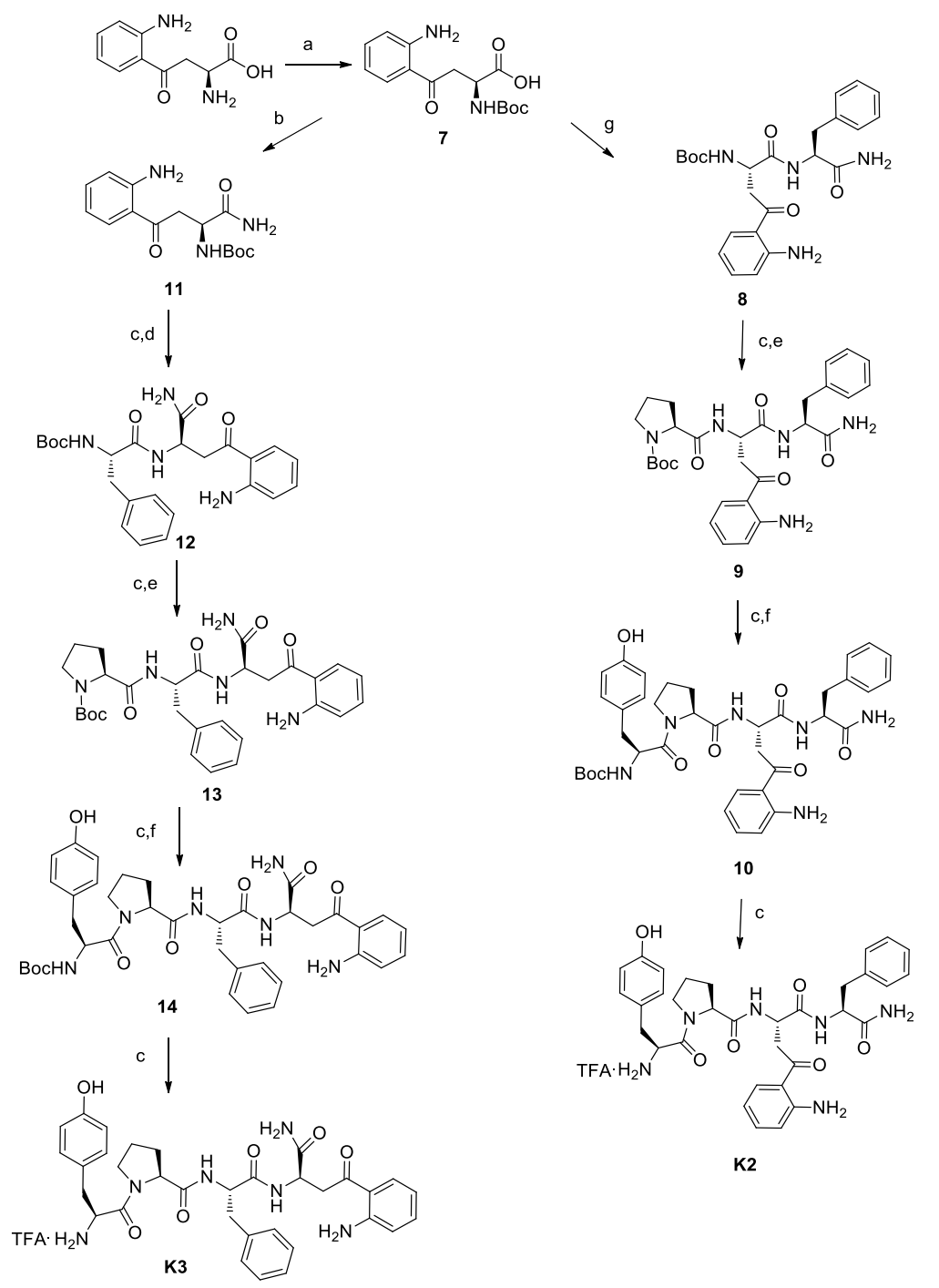

Scheme 2. Synthesis of peptides $\mathbf{K} 2$, K3. Reagents and conditions: (a) $\mathrm{Boc}_{2} \mathrm{O}, \mathrm{NaHCO}_{3}, \mathrm{NaOH} 1 \mathrm{M}$, dioxane $/ \mathrm{H}_{2} \mathrm{O}(2: 1), 10 \mathrm{~min}$ at $0{ }^{\circ} \mathrm{C}$, then $30 \mathrm{~min}$ at r.t. quantitative; (b) $i \mathrm{BCF}, \mathrm{NMM}, \mathrm{NH}_{4} \mathrm{OH}, \mathrm{THF}$, $30 \mathrm{~min}$ at $-10{ }^{\circ} \mathrm{C}$, then $16 \mathrm{~h}$ at r.t., $71 \%$ yield after trituration; (c) TFA/DCM 1:1, $1 \mathrm{~h}$ at r.t. quantitative; (d) Boc-Phe-OH, EDC. $\mathrm{HCl}, \mathrm{HOBt}, \mathrm{DIPEA}, \mathrm{DMF}, 10 \mathrm{~min}$ at $0{ }^{\circ} \mathrm{C}$, then $16 \mathrm{~h}$ at r.t. quantitative; (e) Boc-Pro-OH, EDC.HCl, HOBt, DIPEA, DMF, $10 \mathrm{~min}$ at $0{ }^{\circ} \mathrm{C}, 16 \mathrm{~h}$ at r.t., $72 \%$ yield for 13 after trituration, $81 \%$ yield for 9; (f) Boc-Tyr-OH, EDC.HCl, HOBt, DIPEA, DMF, 10 min at $0{ }^{\circ} \mathrm{C}, 16 \mathrm{~h}$ at r.t., 95\% yield for 14 after trituration, 73\% yield for 10; (g) H-Phe- $\mathrm{NH}_{2}$, EDC.HCl, HOBt, DIPEA, DMF, $10 \mathrm{~min}$ at $0{ }^{\circ} \mathrm{C}$, then $16 \mathrm{~h}$ at r.t., $61 \%$ yield from 7 after trituration.

Finally, linear peptides K4-K6 have been synthesized as methyl ester, acid, and amide derivatives, respectively, starting from L-kyn methyl ester 15 (Scheme 3), prepared following the procedure described in the literature [24,36]. Repeated steps of deprotection/coupling reaction were performed to reach intermediate 19 in high yield after trituration in $\mathrm{Et}_{2} \mathrm{O}$. Boc group removal of intermediate 19 gave K4 in good yield and excellent purity after RP-HPLC purification. Saponification of intermediate compound 19 afforded 20, following the general procedure; the conversion of the latter in the amide $\mathbf{2 1}$ was performed as previously described by Stefanucci et al. [24]. Boc group removal of the linear peptides 20 and 21 afforded products $\mathrm{K} 5$ and $\mathrm{K} 6$ in good yields (72\% and 52\%, respectively), and excellent purity after RP-HPLC purification (98\% and 96\%, respectively). 

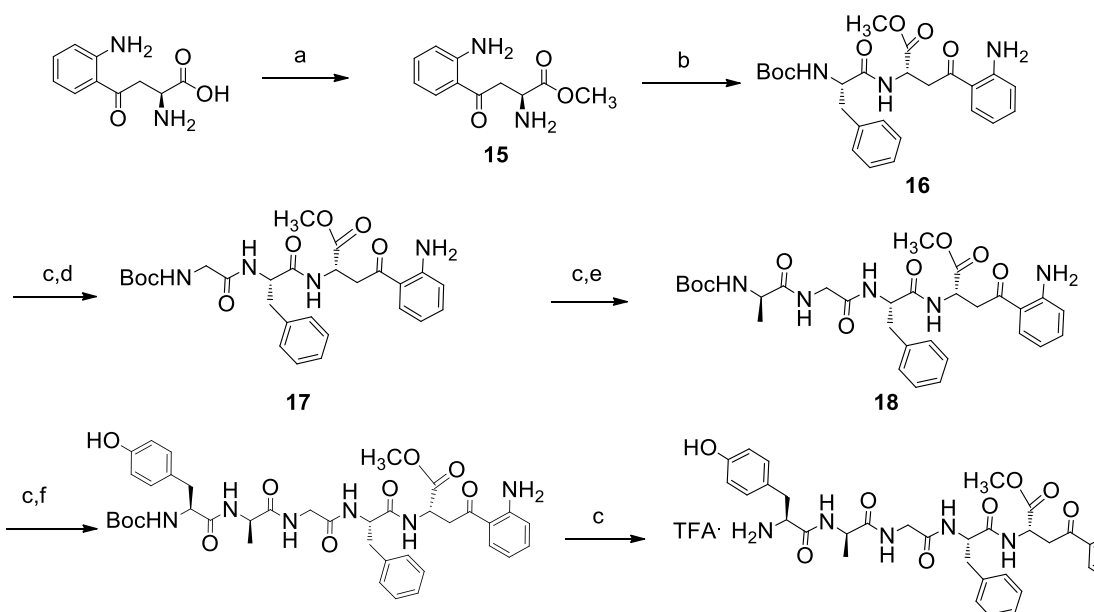

19

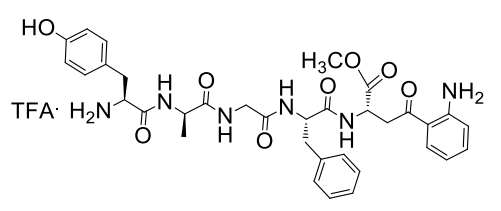

K4
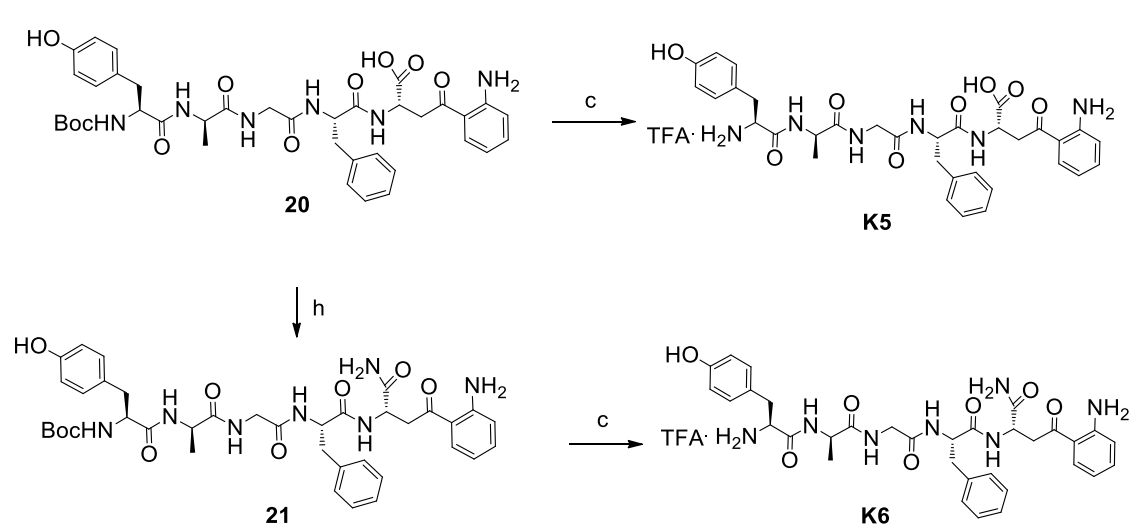

Scheme 3. Synthesis of linear peptides K4-K6. Reagents and conditions: (a) $\mathrm{SOCl}_{2}, \mathrm{MeOH}, 30 \mathrm{~min}$ at $0{ }^{\circ} \mathrm{C}, 16 \mathrm{~h}$ at r.t., quantitative; (b) Boc-Phe-OH, EDC.HCl, HOBt, DIPEA, DMF, $10 \mathrm{~min}$ at $0{ }^{\circ} \mathrm{C}$, then $16 \mathrm{~h}$ at r.t., $60 \%$ after silica gel column chromatography; (c) TFA/DCM 1:1, 1 h at r.t. quantitative; (d) Boc-Gly-OH, EDC.HCl, HOBt, DIPEA, DMF, 10 min at $0{ }^{\circ} \mathrm{C}, 16$ h at r.t., quantitative; (e) Boc-DAla-OH, EDC.HCl, $\mathrm{HOBt}$, DIPEA, DMF, $10 \mathrm{~min}$ at $0{ }^{\circ} \mathrm{C}, 16 \mathrm{~h}$ at r.t., $84 \%$ yield after silica gel column chromatography; (f) Boc-Tyr-OH, EDC.HCl, HOBt, DIPEA, DMF, $10 \mathrm{~min}$ at $0{ }^{\circ} \mathrm{C}, 16 \mathrm{~h}$ at r.t., $72 \%$ yield after trituration; (g) $\mathrm{NaOH} 1 \mathrm{M}$, THF, $3 \mathrm{~h}$ at r.t., quantitative; (h) $i \mathrm{BCF}, \mathrm{NMM}, \mathrm{NH}_{4} \mathrm{OH}$ (aq), THF, $30 \mathrm{~min}$ at $-15^{\circ} \mathrm{C}, 2 \mathrm{~h}$ at r.t., $52 \%$ yield after trituration.

\subsection{In Vitro Studies}

\subsubsection{Binding Assays}

Kyna and its analog (KYNA1) previously reported by Zádor et al. did not directly bind $\mu, \delta$, $\mathrm{K}$-receptors in vitro [37]. However, after chronic and acute administration, they altered opioid receptor function in vivo and in vitro through the NMDA receptor co-localized in the cortex and striatum of mice and rats, though the interaction of opioid receptors and NMDA have been deeply discussed in the literature [37,38]. Kyna is able to bind to the NMDA receptor at micromolar affinity [38]. To test if our novel peptides are able to target both of these systems, they were examined in a receptor binding radioassay using highly specific tritium-labelled primary ligands for opioid and NMDA receptor binding sites. $\left[{ }^{3} \mathrm{H}\right] \mathrm{DAMGO},\left[{ }^{3} \mathrm{H}\right] \mathrm{Il} \mathrm{e}^{5,6}$ Delt II, and $\left[{ }^{3} \mathrm{H}\right] \mathrm{MK}-801$ equilibrium competition (displacement) studies were conducted in rat brain homogenates, while k-opioid receptor tests were performed with $\left[{ }^{3} \mathrm{H}\right] \mathrm{HS} 665$ in guinea pig brain homogenates. The novel ligands showed similar equilibrium inhibitory affinities ( $K_{\mathrm{i}}$ value) in the $\mu$-opioid system as DAMGO except K3 (Table 1, Figure S1A). In the $\delta$-opioid system, the ligands showed lower binding affinity (higher Ki) compared to the selective $\delta$-opioid 
receptor selective agonist Ile ${ }^{5,6}$ Delt II (Figure S1B). In the $k$-opioid receptor system, the compounds showed higher Ki values than that of the selective k-opioid agonist HS665 (Figure S1C). In the NMDA receptor binding assays, the peptides did not produce any competing activity (Figure S1D). Peptide KA1 possesses the best binding affinity, with a Ki value very close to that of the reference compound DAMGO $(1.08 \pm 0.26 \mathrm{nM}$ vs. $0.90 \pm 0.28 \mathrm{nM})$, suggesting that the insertion of kyna into the DAMGO sequence does not impair its binding potency at the $\mu$-opioid receptor. The peptide $\mathbf{K 6}$, presenting the enkephalin-like structure linked to L-kyn C-terminal amide, is able to bind all three opioid receptors with significant affinity, showing a moderate preference for the $\mu$-opioid receptor (affinity ratio 1:18:70 for $\mu, \delta, \mathrm{k}$, respectively), whereas compounds $\mathbf{K} 4$ and $\mathbf{K} 5$ are able to bind only $\mu$ - and $\delta$-opioid receptors. It is reasonable to believe that the $C$-terminal amide derivatization in peptide $\mathbf{K} \mathbf{6}$ confers the ability to bind to the K-opioid receptor. Concerning the endomorphin-2 (EM-2) analogs K2 and K3, the replacement of $\mathrm{Phe}^{3}$ with L-kyn improves the binding affinity and selectivity of $\mathbf{K} 2$ for $\mu$-opioid receptors with respect to the standard compound EM-2, with a weak affinity for k-opioid receptors, while the incorporation of L-Kyn amide in position 4 causes the loss of selectivity for MOR in favor of a modest binding affinity for $\mu$ - and $\delta$-opioid receptors. Peptide $\mathbf{K} 2$ shows a Ki value two-folds lower than that of EM-2 on the $\mu$-opioid receptor, which let us suppose the positive influence of L-Kyn in position 3 on $\mathbf{K} 2$ binding ability.

Table 1. Displacement of $\left[{ }^{3} \mathrm{H}\right]$ DAMGO, $\left[{ }^{3} \mathrm{H}\right] \mathrm{Ile} \mathrm{e}^{5,6}$ Delt II, $\left[{ }^{3} \mathrm{H}\right] \mathrm{HS} 665$, and $\left[{ }^{3} \mathrm{H}\right] \mathrm{MK}-801$ by DAMGO, $\mathrm{Ile}^{5,6}$ Delt II, HS665, MK-801, and oligopeptides in membranes of rat and guinea pig brains. The $\mathrm{IC}_{50}$ values for the MOR, DOR, KOR, and NMDA, according to the competition binding curves (see Figure S1), were converted into equilibrium inhibitory constant $\left(\mathrm{K}_{\mathrm{i}}\right)$ values using the Cheng-Prusoff [39] equation.

\begin{tabular}{|c|c|c|c|c|}
\hline \multirow{2}{*}{ Ligand } & \multicolumn{3}{|c|}{$K_{i}+$ S.E.M. (nM) Opioid System } & \multirow{2}{*}{$\begin{array}{c}\text { NMDA System } \\
\text { MK-801 }^{\mathrm{a}}\end{array}$} \\
\hline & DAMGO $^{\text {a }}$ & Ile $^{5,6}$ Delt II ${ }^{a}$ & HS665 ${ }^{b}$ & \\
\hline DAMGO & $0.90 \pm 0.28$ & n.d. ${ }^{c}$ & n.d. ${ }^{c}$ & n.d. ${ }^{c}$ \\
\hline Ile $^{5,6}$ Delt II & n.d. ${ }^{c}$ & $8.85 \pm 0.77$ & n.d. ${ }^{c}$ & n.d. ${ }^{c}$ \\
\hline HS665 & n.d. ${ }^{c}$ & n.d. ${ }^{c}$ & $2.38 \pm 0.25$ & n.d. ${ }^{c}$ \\
\hline MK-801 & n.d. ${ }^{c}$ & n.d. ${ }^{c}$ & n.d. ${ }^{c}$ & $11.45 \pm 1.04$ \\
\hline EM-2 & $3.16 \pm 0.3$ & n.d. ${ }^{c}$ & n.d. ${ }^{\mathrm{c}}$ & n.d. ${ }^{c}$ \\
\hline KYNA & n.d. ${ }^{c}$ & n.d. ${ }^{c}$ & n.d. ${ }^{c}$ & $>10000$ \\
\hline L-kyn & n.d. ${ }^{c}$ & n.d. ${ }^{c}$ & n.d. ${ }^{c}$ & $>10000$ \\
\hline KA1 & $1.08 \pm 0.26$ & $554.7 \pm 0.8$ & $>10000$ & $>10000$ \\
\hline $\mathrm{K} 2$ & $1.39 \pm 0.30$ & $>10000$ & $1043 \pm 0.3$ & $>10000$ \\
\hline K3 & $197.3 \pm 0.36$ & $158.8 \pm 1.6$ & $>10000$ & $>10000$ \\
\hline K4 & $2.29 \pm 0.28$ & $31.2 \pm 0.7$ & $>10000$ & $>10000$ \\
\hline K5 & $9.11 \pm 0.32$ & $94.4 \pm 0.8$ & $>10000$ & $>10000$ \\
\hline K6 & $1.84 \pm 0.27$ & $32.5 \pm 0.8$ & $127.7 \pm 0.3$ & $>10000$ \\
\hline
\end{tabular}

\subsubsection{Binding-Protein Activation Assays}

The effect of kyn or kyna combined peptides on G-protein activation was investigated in functional $\left[{ }^{35} \mathrm{~S}\right] \mathrm{GTP} \gamma \mathrm{S}$ binding assays in rat and guinea pig brain membranes. All ligands produced dose-dependent stimulations described by sigmoid curves (Figure S2). K6 showed higher efficacy $\left(\mathrm{E}_{\max }\right)$ than DAMGO (Table 2). Moreover, $10 \mu \mathrm{M}$ cyprodime and $10 \mu \mathrm{M}$ naltrindole, which are selective MOR and DOR antagonists, respectively [40,41], significantly reversed the agonist effects of the ligands in rat brain membrane homogenates (Figure S3A). In guinea pig brain membrane homogenates, the ligands did not activate G-protein except K4 and K6 (Figure S3B). Additionally, $10 \mu \mathrm{M}$ norbinaltorphine decreased significantly the agonist effect of $\mathbf{K} \mathbf{4}$ but did not change the effect of $\mathbf{K} \mathbf{6}$ (Table 3). Altogether, these data reveal that peptide KA1 acts as a selective $\mu$-opioid agonist, being able to decrease the GTP $\gamma \mathrm{S}$ binding percentage under the basal level in the presence of $10 \mu \mathrm{M}$ cyprodime. Peptides K2 and $\mathbf{K} 3$ possess a mixed $\mu / \delta$ agonist activity profile, while peptides $\mathbf{K} 4-\mathbf{K} 6$ show a modest mixed 
$\mu / \delta$-opioid receptor agonism. Probably peptide $K 6$ is the strongest mixed $\mu / \delta / \kappa$ opioid agonist due to its ability to bind protein $G$ with an efficacy value over the basal level in presence of each selective opioid antagonist at $10 \mu \mathrm{M}$.

Table 2. G-protein activation DAMGO, and novel oligopeptides in $\left[{ }^{35} \mathrm{~S}\right] \mathrm{GTP} \gamma \mathrm{S}$ binding assays using rat brain membrane homogenates. The values were calculated according to dose-response binding curves.

\begin{tabular}{ccc}
\hline \multirow{2}{*}{ Ligand } & Maximal Stimulation (Efficacy) & Potency \\
\cline { 2 - 3 } & E $_{\mathbf{m a x}} \pm$ S.E.M. (\%) & Log $\mathbf{E C}_{\mathbf{5 0}} \pm$ S.E.M. \\
\hline DAMGO & $172.0 \pm 3.5$ & $-6.384 \pm 0.101$ \\
\hline KA1 & $140.9 \pm 1.4$ & $-6.504 \pm 0.076$ \\
\hline K2 & $121.6 \pm 2.5$ & $-7.535 \pm 0.354$ \\
\hline K3 & $114.0 \pm 2.1$ & $-6.993 \pm 0.422$ \\
\hline K4 & $155.5 \pm 4.8$ & $-6.073 \pm 0.172$ \\
\hline K5 & $149.2 \pm 3.5$ & $-5.990 \pm 0.111$ \\
\hline K6 & $209.7 \pm 3.4$ & $-5.984 \pm 0.054$ \\
\hline
\end{tabular}

Table 3. The maximal G-protein efficacy $\left(E_{\max }\right)$ of novel oligopeptides in the absence or presence of the selective MOR antagonist cyprodime and the selective DOR antagonist naltrindole in rat brain membrane homogenates and in the absence or presence of the selective KOR antagonist norbinaltorphine in guinea pig brain membrane homogenates in $\left[{ }^{35} \mathrm{~S}\right] \mathrm{GTP} \gamma \mathrm{S}$ binding assays. The values were calculated according to bar graphs in Figure S3.

\begin{tabular}{cccccc}
\hline \multirow{2}{*}{ Ligand } & MOR & DOR & \multirow{2}{*}{ Ligand } & KOR \\
\cline { 3 - 4 } & & Ligand + Cyp & Ligand + NTI & & Ligand + Nor-BNI \\
\cline { 2 - 4 } & & \multicolumn{3}{c}{ E $_{\max } \pm$ S.E.M. (\%) } \\
\hline KA1 & $139.6 \pm 8.2$ & $94.7 \pm 3.7^{* *}$ & $102.5 \pm 1.3^{*}$ & $111.7 \pm 1.1$ & $100.7 \pm 6.2^{\mathrm{ns}}$ \\
\hline K2 & $129.9 \pm 8.2$ & $88.0 \pm 3.3^{* *}$ & $88.8 \pm 1.9^{* *}$ & $92.8 \pm 2.0$ & $100.7 \pm 6.0^{\mathrm{ns}}$ \\
\hline K3 & $118.9 \pm 3.0$ & $98.5 \pm 1.2^{* *}$ & $97.8 \pm 1.7^{* *}$ & $95.2 \pm 2.2$ & $106.0 \pm 6.3^{\mathrm{ns}}$ \\
\hline K4 & $160.6 \pm 5.7$ & $101.6 \pm 2.6^{* * *}$ & $103.6 \pm 3.2^{* * *}$ & $125.2 \pm 2.0$ & $104.9 \pm 9.5^{*}$ \\
\hline K5 & $153.1 \pm 5.9$ & $108.8 \pm 1.6^{* *}$ & $103.8 \pm 1.9^{* * *}$ & $106.9 \pm 0.3$ & $110.5 \pm 5.0^{\mathrm{ns}}$ \\
\hline K6 & $211.7 \pm 3.1$ & $108.5 \pm 2.4^{* * *}$ & $113.3 \pm 2.9^{* * *}$ & $139.8 \pm 2.3$ & $142.1 \pm 7.1^{\mathrm{ns}}$ \\
\hline
\end{tabular}

Experimental data were processed by GraphPad Prism 5.0 using bar graphs. ns: not significant; ${ }^{*} p<0.05 ;{ }^{* *} p<0.01$; *** $p<0.001$ based on unpaired $t$-tests.

\subsection{In Vivo Studies}

Data obtained from binding experiments indicate $\mathbf{K} \mathbf{6}$ as the best of the series; thus, tail flick and formalin tests were performed in order to evaluate the effects of this novel peptide in two different pain animal models. The tail flick test measures the time in which the animal withdraws the tail from a thermal nociceptive stimulus; this time is increased by analgesics. Compounds were centrally injected, and the response measured from 15 to $120 \mathrm{~min}$ after the administration. Compounds K6 and DAMGO greatly increase the time of response to thermal nociceptive stimuli and both effects were in the same order to magnitude (Figure 2).

Since it was reported that some opioid peptides such as DAMGO are also peripheral acting [42], we performed a formalin test administering $\mathbf{K} 6$ and DAMGO subcutaneously in mice paws. The formalin test measures the behavioral response to chemical nociceptive stimuli evoked by a formalin diluted solution injected in the mice paw. From 0 to 10 min after the injection, an early phase response occurs with direct stimulation of peripheral nociceptors, while a response to inflammatory pain appears from 15 to $40 \mathrm{~min}$ as a late prolonged phase. Compound $\mathbf{K} 6$ was able to reduce the nociceptive response to formalin in the early phase, whereas a light but not significant reduction was induced in the late phase 
of the formalin test (Figure 3). After the DAMGO injection, we observed a reduction of the nociceptive behavior both early and late in the formalin test (Figure 3). The formalin early phase, which depends upon the direct excitement of sensory neurons through TRPA1 cation channel activation [43] of MORs at the peripheral endings of nociceptors, is responsible for meaningful analgesia [44], and it is not surprising that $\mathrm{K} 6$ and DAMGO reduced formalin-induced nociception in the early phase of the test. The differences observed in the late phase are probably due to a different metabolic fate of $\mathbf{K} \mathbf{6}$ and DAMGO after subcutaneous administration, depending upon the protease activity that might act in different ways on $\mathbf{K} \mathbf{6}$ and DAMGO chemical structures.

TAIL FLICK TEST

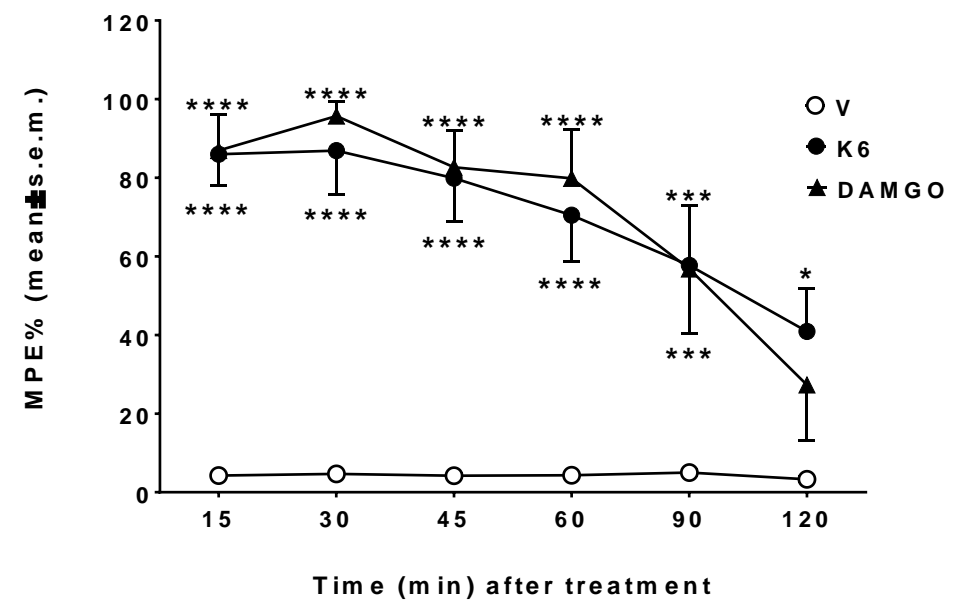

Figure 2. The effect of $\mathbf{K} \mathbf{6}$ and DAMGO in the tail flick test. Compounds were administered in the left cerebral ventricle at the dose of $10 \mu \mathrm{g} / 10 \mu \mathrm{L}$, and the time to respond to thermal stimuli measured from 15 to $120 \mathrm{~min}$. V is for vehicle-treated animals. Statistical analysis: two-way ANOVA followed by Sidak's multiple comparisons test. ${ }^{*}$ is for $p<0.05,{ }^{* * *}$ is for $p<0.001$, and ${ }^{* * * *}$ is for $p<0.0001 \mathrm{vs.} \mathrm{V.}$ $\mathrm{n}=7$.

\section{FORM ALIN TEST}

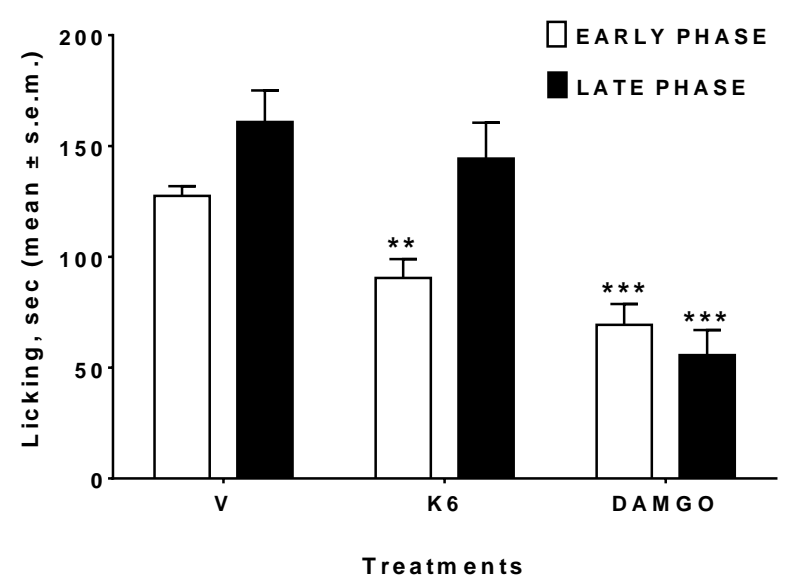

Figure 3. The effect of $\mathbf{K} \mathbf{6}$ and DAMGO in the formalin test. Compounds were administered subcutaneously (s.c.) in the dorsal hind paw of mice at the dose of $100 \mu \mathrm{g} / 20 \mu \mathrm{L}, 15 \mathrm{~min}$ before a s.c. injection of dilute formalin solution ( $1 \%$ in saline, $20 \mu \mathrm{L} / \mathrm{paw})$. Early phase represents the formalin-induced nociceptive behavior recorded from 0 to $10 \mathrm{~min}$ after formalin injection; late phase is for the formalin-induced nociceptive behavior recorded from 15 to $40 \mathrm{~min}$ after formalin injection. $\mathrm{V}$ is for vehicle-treated animals. Statistical analysis: one-way ANOVA followed by Holm-Sidak's multiple comparisons test. ${ }^{* *}$ is for $p<0.01$ and ${ }^{* * *}$ is for $p<0.001$ vs. V. $\mathrm{n}=7$. 


\subsection{Plasma Stability Results}

The plasma stability of compound $\mathbf{K} \mathbf{6}$ was tested by incubation in human plasma at $37{ }^{\circ} \mathrm{C}$. The degradation curve (Figure 4) was built by plotting the total amount of remaining peptide (expressed as $\mu \mathrm{g} / \mathrm{mL}$ ) vs. time (minutes). Concentration data were obtained in triplicate and analyzed as simple linear regression using GraphPad 8.3.1. The novel compound exhibits good stability in human plasma, showing a $\mathrm{t}_{1 / 2}=47 \mathrm{~min}$, according to the results obtained from the tail flick test after i.c.v. administration.

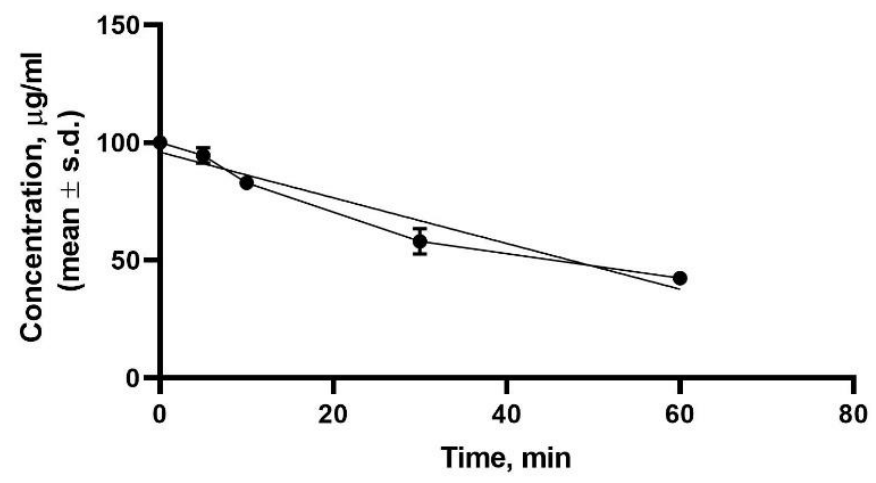

Figure 4. Stability of compound $\mathrm{K} 6$ in human plasma. Concentration of $\mathrm{K} 6 \mathrm{in} \mu \mathrm{g} / \mathrm{mL}$ measured from 0 to $60 \mathrm{~min}$ in triplicate.

\section{Conclusions}

Chemical modification of endogenous opioid peptides promotes the development of novel analogs with increased potency and improved pharmacokinetic properties, e.g., the synthetic bivalent peptide biphalin enhanced stroke immunohistochemical and behavioral neuroprotection in comparison to DPDPE and DAMGO, reducing glutamate toxicity and oxidative stress [45-48]. Metabolites of the KP, especially kyna and L-kyn, play crucial roles in maintaining the normal brain function, preventing the over-activation of excitatory amino acid receptors, thus offering novel therapeutical opportunities for brain neuroprotection. In this work, we have synthesized six novel opioid analogs incorporating the L-kyn and kyna residues at different positions of several opioid peptide scaffolds. They were characterized by in vitro and in vivo assays to evaluate their ability to bind the NMDA/opioid receptors and to induce analgesic effects after i.c.v. and s.c. administration. These novel peptides do not bind to the NMDA receptors, and some of them showed good/high affinity for opioid receptors with different selectivity profiles. In particular, KA1 exhibits the binding constant $(\mathrm{Ki}=1.08)$ very close to that of DAMGO for the $\mu$-opioid receptor and a pronounced selectivity but medium-low efficacy $\left(E_{\max }=139 \%\right)$; thus the esterification of the ethanolamine portion with kyna does not add any particular advantage to the parent peptide DAMGO. On the other hand, the presence of L-kyn residue in place of native Phe in position 3 (K2) leads a potent and selective opioid fragment toward MOR (selectivity ration $\mu / \delta / \kappa=1: 10,000: 750$ ), whereas the substitution in position 4 (K3) leads to a weak and unselective agonist at MOR and DOR. In the analogs K4-K6, the kyna residue was inserted in the fifth position of the YaGP peptide, with different $C$-terminus, respectively, methyl ester, free carboxylic acid, and amide. $\mathbf{K} 4$ and $\mathbf{K} \mathbf{5}$ show a similar mixed binding affinity for MOR and DOR, with a preference for MOR and none or weak affinity for KOR.

On the contrary, peptide $\mathbf{K} 6$ shows an interesting behavior since it is able to bind all three opioid receptors with binding affinity ranging from high to modest $\left(\mathrm{Ki}^{\mu}=1.84 \mathrm{nM}, \mathrm{Ki}^{\delta}=32.5 \mathrm{nM}\right.$, $\left.\mathrm{Ki}^{\mathrm{K}}=127.7 \mathrm{nM}\right)$, with a potency $\left(\log \mathrm{EC}_{50}=-5.598\right)$ and efficacy at $\mathrm{MOR}\left(\mathrm{E}_{\max }=211 \%\right)$ higher than that of DAMGO $\left(E_{\max }=172 \%\right)$. Its activity on the GTP $\gamma \mathrm{S}$ binding assay on rat brain membrane and guinea pig ileum is well antagonized by the co-administration of the selective antagonists for MOR and DOR at $10 \mu \mathrm{M}$ concentration, prompting us to deeply investigate its anti-nociceptive effect in vivo. The formalin test, which is a model of inflammatory pain, revealed that the antinociceptive 
effect exerted by $\mathbf{K} \mathbf{6}$ after subcutaneous administration is significant only in the early phase, whereas DAMGO is also active in the late phase. In the tail flick test, the $\mathbf{K} \mathbf{6}$ analgesic profile after i.c.v. administration is superimposable to that of DAMGO, according to a good stability profile in human plasma. These data are encouraging to further develop opioid peptides containing kynurenine moieties since the insertion of kyna and kyn in our opioid model improved, in some cases, the binding affinity and was able to modulate the selectivity. Also, the possible role played by the metabolism of these peptides and their possible implication in different neuropathic and chronic pain models is unknown and worth further investigation.

Supplementary Materials: The following are available online at http://www.mdpi.com/2218-273X/10/2/284/s1, Figure S1: MOR (A), DOR (B), KOR (C) and NMDA (D) binding affinity of the novel oligopeptides, Figure S2: The effect of oligopeptides on G-protein activity compared to DAMGO in [ $\left.{ }^{35} \mathrm{~S}\right] \mathrm{GTP} \gamma \mathrm{S}$ binding assay in rat brain membrane homogenates, Figure S3: The effect of novel oligopeptides on G-protein activity in $\left[{ }^{35} \mathrm{~S}\right] \mathrm{GTP} \gamma \mathrm{S}$ binding assays in the absence or presence of the selective MOR antagonist cyprodime (Cyp) and the selective DOR antagonist naltrindole (NTI) in rat brain membrane homogenates (Figure A) and the selective KOR antagonist norbinaltorphine (nor-BNI) in guinea pig brain membrane homogenates (Figure B).

Author Contributions: Conceptualization, A.S. and S.B.; Data curation, E.S., F.Z., S.P. and G.Z.; Formal analysis, F.Z. and L.V.; Investigation, A.S., M.N. and S.P.; Methodology, E.S. and M.P.D.; Validation, S.B.; Writing-original draft, A.S.; Writing-review \& editing, A.M., L.V. and S.B. All authors have read and agreed to the published version of the manuscript.

Funding: This research was supported by the project GINOP 2.3.2-15-2016-00034, provided by National Research, Development and Innovation Office (NKFI), Budapest, Hungary, and the Ministry of Human Capacities, Hungary grant 20391-3/2018/FEKUSTRAT.

Conflicts of Interest: The authors declare no conflict of interest.

\section{Abbreviations}

\begin{tabular}{|c|c|}
\hline $\mathrm{KP}$ & kynurenine pathway \\
\hline kyn & kynurenine \\
\hline kyna & kynurenic acid \\
\hline FDA & Food and Drug Administration \\
\hline CNS & central nervous system \\
\hline BBB & blood brain barrier \\
\hline GPR35 & G protein-coupled receptor 35 \\
\hline SVCT2 & Sodium-dependent vitamin $\mathrm{C}$ transporter 2 \\
\hline MOR & $\mu$-opioid receptor; DOR, $\delta$-opioid receptor \\
\hline DOR & $\delta$-opioid receptor \\
\hline KOR & k-opioid receptor; GPCRs, G protein coupled receptors \\
\hline GPCRs & G protein coupled receptors \\
\hline NMR & Nuclear magnetic resonance \\
\hline TFA & trifloroacetic acid \\
\hline $\mathrm{ACN}$ & acetonitrile \\
\hline RP-HPLC & Reverse Phase High performance liquid chromatography \\
\hline TMS & trimethylsilane \\
\hline ESI & Electrospray ionization \\
\hline LRMS & Low Resolution Mass Spectroscopy \\
\hline HOBt & 1-hydroxybenzotriazole \\
\hline DMAP & 4-Dimethylaminopyridine \\
\hline $\mathrm{EDC} \cdot \mathrm{HCl}$ & 1-Ethyl-3-(3-dimethylaminopropyl)carbodiimide hydrochloride \\
\hline EtOAc & ethyl acetate \\
\hline THF & tetrahydrofurane \\
\hline NMM & N-methylmorpholine \\
\hline
\end{tabular}




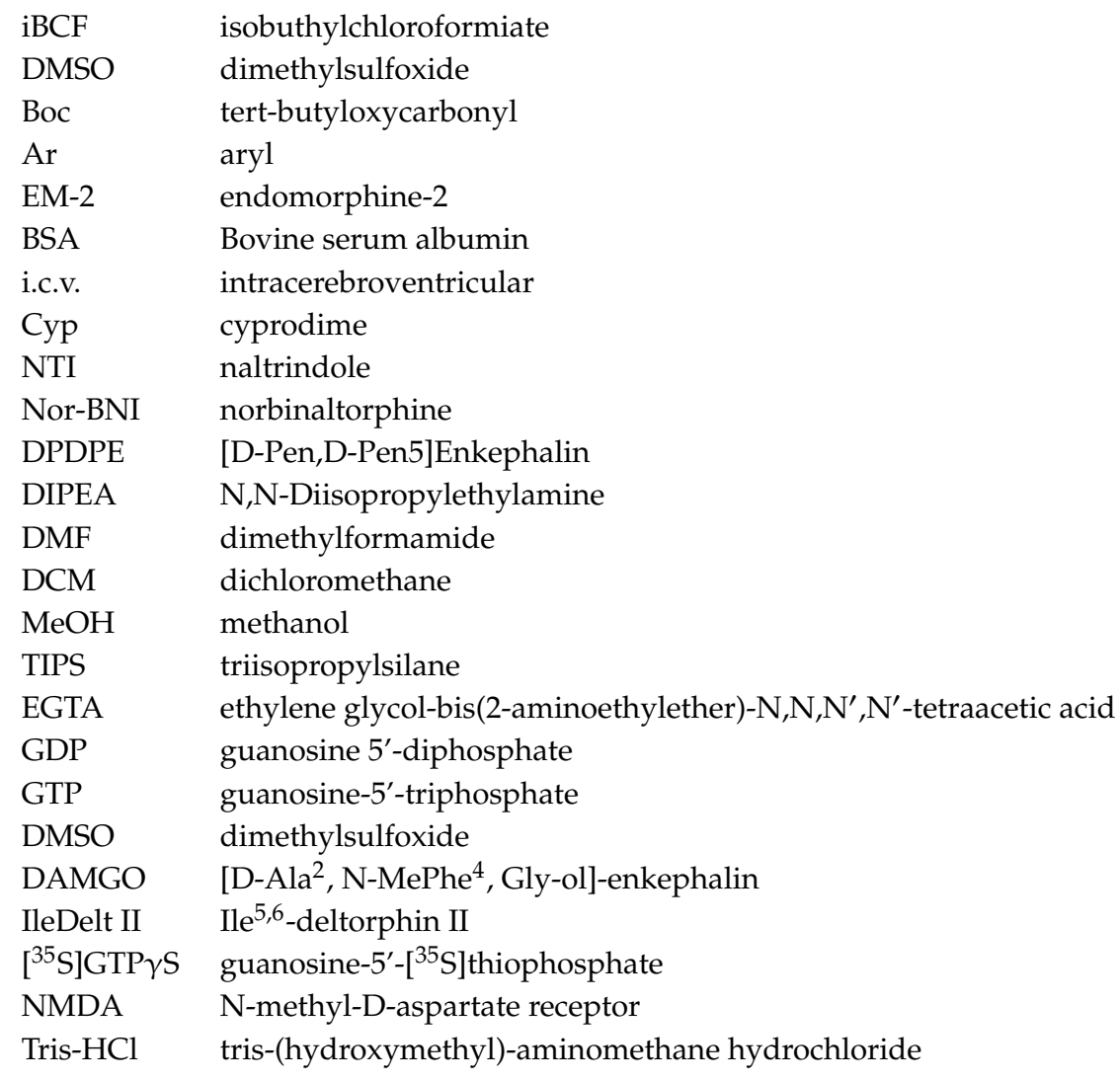

\section{References}

1. Cervenka, I.; Agudelo, L.Z.; Ruas, J.L. Kynurenines: Tryptophan's metabolites in exercise, inflammation, and mental health. Science 2017, 357, 9794. [CrossRef]

2. Ye, Y.; Xia, Z.; Zhang, D.; Sheng, Z.; Zhang, P.; Zhu, H.; Xu, N.; Liang, S. Multifunctional pharmaceutical effects of the antibiotic daptomycin. BioMed Res. Int. 2019, 2019, 8609218. [CrossRef] [PubMed]

3. Chuang, P.-H.; Hsieh, P.-W.; Yang, Y.-L.; Hua, K.-F.; Chang, F.-R.; Shiea, J.; Wu, S.-H.; Wu, Y.-C. Cyclopeptides with Anti-inflammatory Activity from Seeds of Annona Montana. J. Nat. Prod. 2008, 71, 1365-1370. [PubMed]

4. Ellis-Steinborner, S.T.; Scanlon, D.; Musgrave, I.F.; Nha Tran, T.T.; Hack, S.; Wang, T.; Abell, A.D.; Tyler, M.J.; Bowie, J.H. An unusual kynurenine-containig opioid tetrapeptide from the skin gland secretion of the Australian red tree frog Litoria rubella. Sequence determination by electrospray mass spectrometry. Rapid Commun. Mass Spectrom. 2011, 25, 1735-1740. [CrossRef] [PubMed]

5. Guillemin, G.J.; Kerr, S.J.; Smythe, G.A.; Smith, D.G.; Kapoor, V.; Armati, P.J.; Croitoru, J.; Brew, B.J. Kynurenine pathway metabolism in human astrocytes: A paradox for neuronal protection. J. Neurochem. 2001, 78, 842-853.

6. Schwarcz, R.; Bruno, J.P.; Muchowski, P.J.; Wu, H.-Q. Kynurenines in the mammalian brain: When physiology meets pathology. Nat. Rev. Neurosci. 2012, 13, 465-477.

7. Vécsei, L.; Szalárdy, L.; Fülöp, F.; Toldi, J. Kynurenines in the CNS: Recent advances and new questions. Nat. Rev. Drug. Discov. 2013, 12, 64-82. [CrossRef]

8. Yeganeh Salehpour, M.; Mollica, A.; Momtaz, S.; Sanadgol, N.; Farzaei, M.H. Melatonin and multiple sclerosis: From plausible neuropharmacological mechanisms of action to experimental and clinical evidence. Clin. Drug Investig. 2019, 39, 607-624. [CrossRef]

9. Birch, P.J.; Grossman, C.J.; Hayes, A.G. Kynurenate and FG9041 have both competitive and non-competitive antagonist actions at excitatory amino acid receptors. Eur. J. Pharmacol. 1988, 151, 313-315. [CrossRef]

10. Perkins, M.N.; Stone, T.W. Actions of kynurenic acid and quinolinic acid in the rat hippocampus in vivo. Exp. Neurol. 1985, 88, 570-579. [CrossRef]

11. Wang, J.; Simonavicius, N.; Wu, X.; Swaminath, G.; Reagan, J.; Tian, H.; Ling, L. Kynurenic acid as a Ligand for Orphan G Protein-coupled Receptor GPR35. J. Biol. Chem. 2006, 281, 22021-22028. [CrossRef] [PubMed] 
12. Shore, D.M.; Reggio, P.H. The therapeutic potential of orphan GPCRs, GPR35 and GPR55. Front. Pharmacol. 2015, 6, 69. [CrossRef] [PubMed]

13. Bonina, F.P.; Arenare, L.; Ippolito, R.; Boatto, G.; Battaglia, G.; Bruno, V.; de Caprariis, P. Synthesis, pharmacokinetics and anticonvulsant activity of 7-chlorokynurenic acid prodrugs. Int. J. Pharm. 2000, 202, 79-88. [CrossRef]

14. Luhavaya, H.; Sigrist, R.; Chekan, J.R.; McKinnie, S.M.K.; Moore, B.S. Biosynthesis of 1-4-Chlorokynurenine, an antidepressant prodrug and a non-proteinogenic amino acid found in lipopeptide. Antibiotics 2019, 58, 8394-8399.

15. Manfredini, S.; Vertuani, S.; Pavan, B.; Vitali, F.; Scaglianti, M.; Bortolotti, F.; Biondi, C.; Scatturin, A.; Prasad, P.; Dalpiaz, A. Design, synthesis and activity of ascorbic acid prodrugs of nipecotic, kynurenic and diclophenamic acids, liable to increase neurotropic activity. J. Med. Chem. 2002, 45, 559-562. [CrossRef]

16. Vamos, E.; Pardutz, A.; Klivenyi, P.; Toldi, J.; Vecsei, L. The role of kynurenines in disorders of the central nervous system: Possibilities for neuroprotection. J. Neurol. Sci. 2009, 283, 21-27. [CrossRef]

17. Knyihár-Csillik, E.; Toldi, J.; Mihály, J.A.; Krisztin-Péva, B.; Chadaide, Z.; Németh, H.; Vécsei, L. Kynurenine in combination with probenecid mitigates the stimulation-induced increase of c-fos immunoreactivity of the rat caudal trigeminal nucleus in an experimental migraine model. J. Neural. Transm. 2007, 114, 417-421. [CrossRef]

18. Gábor, N.-G.; Dvorácskó, S.; Bohár, Z.; Benyhe, S.; Tömböly, C.; Párdutz, A.; Vécsei, L. Interactions between the kynurenine and the endocannabinoid system with special emphasis on migraine. Int. J. Mol. Sci. 2017, 18, 1617. [CrossRef]

19. Stone, T.W.; Caroline, M.; Forrest, M.; Darlington, L.G. Kynurenine pathway inhibition as a therapeutic strategy for neuroprotection. FEBS J. 2012, 279, 1386-1397. [CrossRef]

20. Deora, G.S.; Kantham, S.; Chan, S.; Dighe, S.N.; Veliyath, S.K.; McColl, G.; Parat, M.O.; McGeary, R.P.; Ross, B.P. Multifunctional analogs of kynurenic acid for the treatment of Alzheimer's disease: Synthesis, pharmacology, and molecular modeling studies. ACS Chem. Neurosci. 2017, 8, 2667-2675. [CrossRef]

21. Zádori, D.; Nyiri, G.; Szonyi, A.; Szatmári, I.; Fülöp, F.; Toldi, J.; Freund, T.F.; Vécsei, L.; Klivényi, P. Neuroprotective effects of a novel kynurenic acid analogue in a transgenic mouse model of Huntington's disease. J. Neurol. Transm. 2011, 18, 865-875. [CrossRef] [PubMed]

22. Ghilardi, A.; Pezzoli, D.; Bellucci, M.C.; Malloggi, C.; Negri, A.; Sganappa, A.; Tedeschi, G.; Candiani, G.; Volonterio, A. Synthesis of multifunctional PAMAM-Aminoglycoside conjugates with enhanced transfection efficiency. Bioconjug Chem. 2013, 24, 1928-1936. [CrossRef]

23. Tsentalovich, Y.P.; Yanshole, V.V.; Polienko, Y.F.; Morozov, S.V.; Grigor'ev, I.A. Deactivation of excited states of kynurenine covalently linked to nitroxides. Photochem. Photobiol. 2011, 87, 22-31. [CrossRef] [PubMed]

24. Stefanucci, A.; Novellino, E.; Mirzaie, S.; Macedonio, G.; Pieretti, S.; Minosi, P.; Szúcs, E.; Erdei, A.I.; Zádor, F.; Benyhe, S.; et al. Opioid receptor activity and analgesic potency of DPDPE peptide analogues containing a xylene bridge. ACS Med. Chem. Lett. 2017, 8, 449-454. [CrossRef] [PubMed]

25. Spetea, M.; Berzetei-Gurske, I.P.; Guerrieri, E.; Schmidhammer, H. Discovery and pharmacological evaluation of a diphenethylamine derivative (HS665), a highly potent and selectivek-opioid receptor agonist. J. Med. Chem. 2012, 55, 10302-10306. [CrossRef] [PubMed]

26. Oktem, H.A.; Moitra, J.; Benyhe, S.; Tóth, G.; Lajtha, A.; Borsodi, A. Opioid receptor labeling with the chloromethyl ketone derivative of [3H]Tyr-D-Ala-Gly-(Me)Phe-Gly-ol (DAMGO) II: Covalent labeling of mu opioid binding site by 3H-Tyr-D-Ala-Gly-(Me)Phe chloromethyl ketone. Life Sci. 1991, 48, 1763-1768. [CrossRef]

27. Guerrieri, E.; Mallareddy, J.R.; Tóth, G.; Schmidhammer, H.; Spetea, M. Synthesis and pharmacological evaluation of $[(3) \mathrm{H}] \mathrm{HS} 665$, a novel, highly selective radioligand for the kappa opioid receptor. ACS Chem. Neurosci. 2015, 6, 456-463. [CrossRef]

28. Basu, N.; Scheuhammer, A.M.; Rouvinen-Watt, K.; Grochowina, N.; Evans, R.D.; O’Brien, M.; Chan, H.M. Decreased N-methyl-d-aspartic acid (NMDA) receptor levels are associated with mercury exposure in wild and captive mink. Neurotoxicology 2007, 28, 587-593. [CrossRef]

29. Benyhe, S.; Farkas, J.; Tóth, G.; Wollemann, M. Met5-enkephalin-Arg6-Phe7, an endogenous neuropeptide, binds to multiple opioid and nonopioid sites in rat brain. J. Neurosci. Res. 1997, 48, 249-258. [CrossRef] 
30. Zádor, F.; Kocsis, D.; Borsodi, A.; Benyhe, S. Micromolar concentrations of rimonabant directly inhibits delta opioid receptor specific ligand binding and agonist-induced G-protein activity. Neurochem. Int. 2014, 67, 14-22. [CrossRef]

31. Bradford, M.M. A rapid and sensitive method for the quantitation of microgram quantities of protein utilizing the principle of protein-dye binding. Anal. Biochem. 1976, 72, 248-254. [CrossRef]

32. Sim, L.J.; Selley, D.E.; Childers, S.R. In vitro autoradiography of receptor-activated G proteins in rat brain by agonist-stimulated guanylyl 5'-[gamma-[35S]thio]-triphosphate binding. Proc. Natl. Acad. Sci. USA 1995, 92, 7242-7246. [CrossRef] [PubMed]

33. Traynor, J.R.; Nahorski, S.R. Modulation by mu-opioid agonists of guanosine-5'-O-(3-[35S]thio)triphosphate binding to membranes from human neuroblastoma SH-SY5Y cells. Mol. Pharmacol. 1995, 47, 848-854. [PubMed]

34. Neises, B.; Steglich, W. Simple Method for the Esterification of Carboxylic Acids. Angew. Chem. Int. Ed. Engl. 1978, 17, 522-524. [CrossRef]

35. Mollica, A.; Costante, R.; Stefanucci, A.; Pinnen, F.; Luisi, G.; Pieretti, S.; Borsodi, A.; Bojinik, E.; Benyhe, S. Hybrid peptides endomorphin-2/DAMGO: Design, synthesis and biological evaluation. Eur. J. Med. Chem. 2013, 68, 167-177. [CrossRef]

36. Stefanucci, A.; Lei, W.; Hruby, V.J.; Macedonio, G.; Luisi, G.; Carradori, S.; Streicher, J.M.; Mollica, A. Fluorescent-labeled bioconjugates of the opioid peptides biphalin and DPDPE incorporating fluorescein-maleimide linkers. Future Med. Chem. 2017, 9, 859-869. [CrossRef]

37. Zádor, F.; Samavati, R.; Szlavicz, E.; Tuka, B.; Bojnik, E.; Fulop, F.; Toldi, J.; Vecsei, L.; Borsodi, A. Inhibition of opioid receptor mediated G-Protein activity after chronic administration of kynurenic acid and its derivative without direct binding to opioid receptors. CNS Neurol. Disord. Drug Targets 2014, 13, 1520-1529. [CrossRef]

38. Kemp, J.A.; Grimwood, S.; Foster, A.C. Characterization of the antagonism of excitatory amino acid receptors in rat cortex by kynurenic acid. Br. J. Pharmacol. 1987, 91, 314P.

39. Cheng, Y.-C.; Prusoff, W.H. Relationship between the inhibition constant (K1) and the concentration of inhibitor which causes 50 per cent inhibition (I50) of an enzymatic reaction. Biochem. Pharmacol. 1973, 22, 3099-3108.

40. Márki, A.; Monory, K.; Otvos, F.; Tóth, G.; Krassnig, R.; Schmidhammer, H.; Traynor, J.R.; Roques, B.P.; Maldonado, R.; Borsodi, A. Mu-opioid receptor specific antagonist cyprodime: Characterization by in vitro radioligand and $\left[{ }^{35} \mathrm{~S}\right] \mathrm{GTP} \gamma \mathrm{S}$ binding assays. Eur. J. Pharmacol. 1999, 383, 209-214. [CrossRef]

41. Portoghese, P.S.; Sultana, M.; Takemori, A.E. Naltrindole, a highly selective and potent non-peptide delta opioid receptor antagonist. Eur. J. Pharmacol. 1988, 146, 185-186. [CrossRef]

42. Smith, H.S. Peripherally-acting opioids. Pain Physician 2008, 11, 121-132.

43. McNamara, C.R.; Mandel-Brehm, J.; Bautista, D.M.; Siemens, J.; Deranian, K.L.; Zhao, M.; Hayward, N.J.; Chong, J.A.; Julius, D.; Moran, M.M.; et al. TRPA1 mediates formalin-induced pain. Proc. Natl. Acad. Sci. USA 2007, 104, 13525-13530. [CrossRef] [PubMed]

44. Stein, C. Opioid receptors. Annu. Rev. Med. 2016, 67, 433-451. [CrossRef]

45. Yang, L.; Wang, H.; Shah, K.; Karamyan, V.T.; Abbruscato, T.J. Opioid receptor agonists reduce brain edema in stroke. Brain Res. 2011, 1383, 307-316. [CrossRef]

46. Yang, L.; Shah, K.; Wang, H.; Karamyan, V.T.; Abbruscato, T.J. Characterization of neuroprotective effects of biphalin, an opioid receptor agonist, in a model of focal brain ischemia. J. Pharmacol. Exp. Ther. 2011, 339, 499-508. [CrossRef]

47. Yang, L.; Islam, M.R.; Karamyan, V.T.; Abbruscato, T.J. In vitro and in vivo efficacy of a potent opioid receptor agonist, biphalin, compared to subtype-selective opioid receptor agonists for stroke treatment. Brain Res. 2015, 1609, 1-11. [CrossRef]

48. Davis, T.P.; Abbruscato, T.J.; Egleton, R.D. Peptides at the blood brain barrier: Knowing me knowing you. Peptides 2015, 72, 50-56. [CrossRef]

(C) 2020 by the authors. Licensee MDPI, Basel, Switzerland. This article is an open access article distributed under the terms and conditions of the Creative Commons Attribution (CC BY) license (http://creativecommons.org/licenses/by/4.0/). 